\title{
Reduction of Excessive Trimming and Reject Leather by Integration of 7 QC Tools and QC Story Formula: The Case Report of Sheba Leather PLC
}

\author{
Haftu Hailu1 ${ }^{1}$ Hideki Tabuchi ${ }^{2 *}$, Hiroshi Ezawa ${ }^{2}$ and Kassu Jilcha ${ }^{3}$
}

${ }^{1}$ Public Service and Human Resource Development Ministry, Ethiopia Kaizen Institute, Addis Ababa, Ethiopia

2Japan International Cooperation Agency, Tokyo, Japan

${ }^{3}$ Department of Mechanical Engineering, School of Chemical and Mechanical Engineering, Kombolcha Institute of Technology, Wollo University, Desie, Ethiopia

\begin{abstract}
At the present time most of Ethiopian leather manufacturing industries are facing tough competition globally due to deteri-orated quality of leather. Clearly known that poor quality results in increasing manufacturing cost. Lastly, the industry becomes unprofitable. In addition, the industries are forced to lose their customers. Sheba leather Industry PLC is one of Ethiopian leather manufacturing industry facing this problem. So, the purpose of the project is to decrease extreme trimmed and rejected leather, to introduce a system that is capable of solving the problem, to expand findings to other sections of the industry. There was a problem of trimmed and rejected skin leather at re-tanning and crust preparation section. $14,879.92 \mathrm{~kg}$ of trimmed skin leather and 8,164 pieces of rejected leather. The problem solving methodology approach was used during the project work to reduce both trimmed and rejected leather. Quality control 7 tools were also applied as per the nature of the steps of problem solving. The findings after completion of the implementation period the excessive trimmed leather is reduced to $8,524 \mathrm{~kg}$ by $42.71 \%$ improvement. The rejected leather of minimized to 5,241 pieces of leather by $35.80 \%$ improvement. In addition, systems like standard operation procedure, standardization of four basic autonomous maintenance activities, quality control process chart and operator skill analysis are introduced on potential areas. Besides, the area of the finished leather also improves by $2.2 \%$ relative to the input size of the leather. Finally, the department managers took responsibility to sustain the substantial improvements and expand these systems to hide production section of the company.
\end{abstract}

Keywords: Minimization; Excessive; Leather; Quality

\section{Introduction}

The Ethiopia Kaizen Institute in collaboration with Japanese International Cooperation Agency - JICA implementing intermediate level kaizen at companies which have been successfully completing the first level of kaizen implementation in considering their activities on sustaining. Now a days, 12 manufacturing industries are know implementing the intermediate level kaizen at nationwide. From these companies, Sheba Leather Industry is one of these companies currently implementing. The reporter wants to discuss Kick-off was held with Sheba top and middle managements by performing the following activities during the first ICT visit: 'Diagnosis of the current activity of Kaizen office, shoes and tannery section, 'Discussion with HRD manager on how to continue ICT activity and their necessary requirement, 'Conduct Kick off meeting for 13 management members with JICA expert, including: Objective of the project, Managements expectation from the advanced kaizen, Applicable technics by factory type, Schedule of ICT with Detail time schedule, Benefits of the project, CSFs for the successful completion of the project associated with top, middle mgmt. and employees, Wet blanket lists for the project, Discussion whether we exceed their expectation or not, 'Discussion with JICA expert on how to proceed the project activity.

Highlight training for top and middle managements including selected divisions and supervisors was given by performing the following activities. Preparation of training material for top and middle managements. High light training about applicable techniques were given for 20 male management members: TQM, TPS, TPM, A-KPT, PRODUCTION SCHEDULING, MATERIAL REQUIREMENT PLANNING. Company challenges or chronic problems were exploited from the management during discussion. In addition, Extracted challenges from the company convenient three year strategic business plan as seen in the next slide.

\section{Establishing cross functional teams: A-KPT}

Six number of cross functional teams are organized from eleven departments which contains 38 members ( 33 male and 5 female). Two CFT's are given for each EKI trainee. Reduction of excessive trimming and rejection leather CFT is one of those main teams that belong to me. Mr. Haftu Hailu took leading role of the project activities. The team comprise 6 members (5 male and 1 female). Hiluf Birhane and Henock Kassahun from tannery quality; G/meskel G/yohannese, Abrham W/ rufael and Alganesh Cherkos from Tannery production; Yordanos abreha from supply.

\section{Material and Methods}

Different materials like books, journals, and training materials were reviewed to learn more about the integration of 7 quality control tools and problem solving approach. Check sheet, pareto diagram, cause and effect analysis, control chart and process flow chart were applied to the quality control story formula. The problem solving approach methodology is shown in Figure 1 below.

*Corresponding author: Hideki Tabuchi, Japan International Cooperation Agency, Tokyo, Japan, Tel: +81-3-5226-6660; E-mail: tabuchi@jds21.co

Received August 04, 2017; Accepted August 24, 2017; Published August 30, 2017

Citation: Hailu H, Tabuchi H, Ezawa H, Jilcha K (2017) Reduction of Excessive Trimming and Reject Leather by Integration of $7 \mathrm{QC}$ Tools and QC Story Formula: The Case Report of Sheba Leather PLC. Ind Eng Manage 6: 223. doi:10.4172/21690316.1000223

Copyright: (c) 2017 Hailu H, et al. This is an open-access article distributed under the terms of the Creative Commons Attribution License, which permits unrestricted use, distribution, and reproduction in any medium, provided the original author and source are credited. 


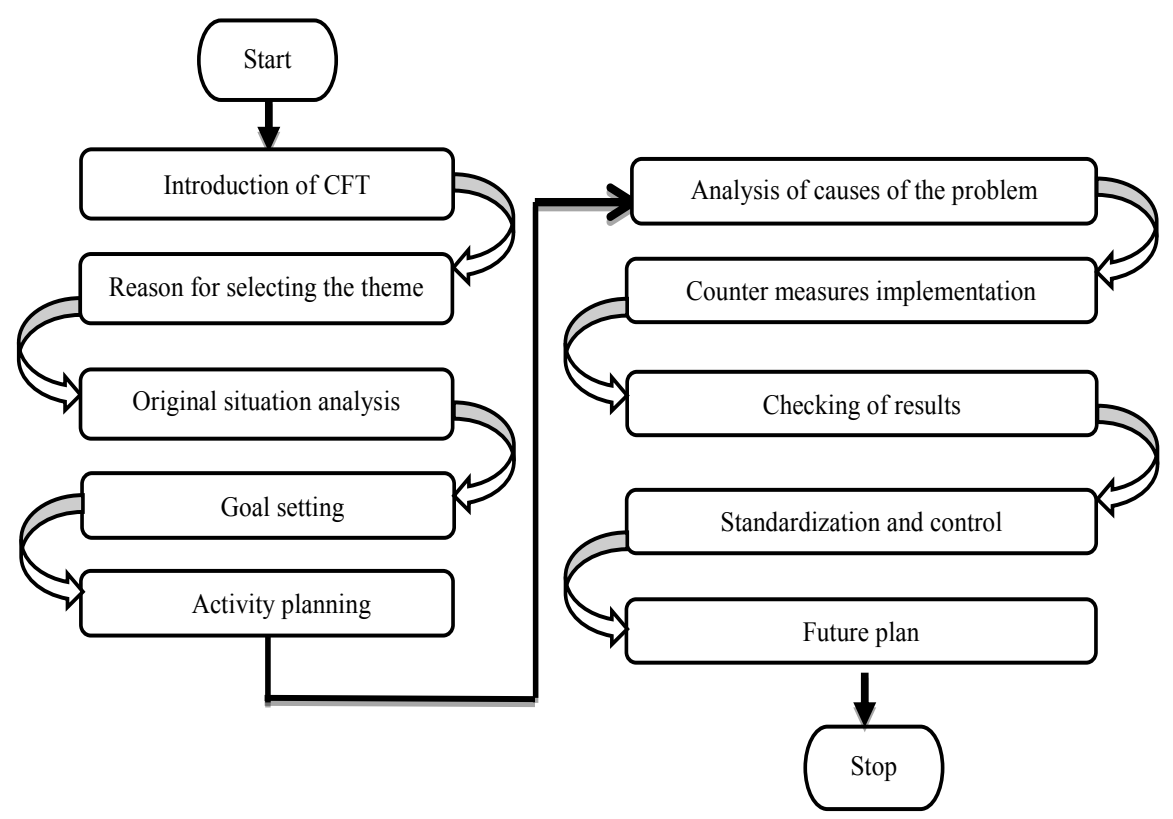

Figure 1: Flowchart of methodology.

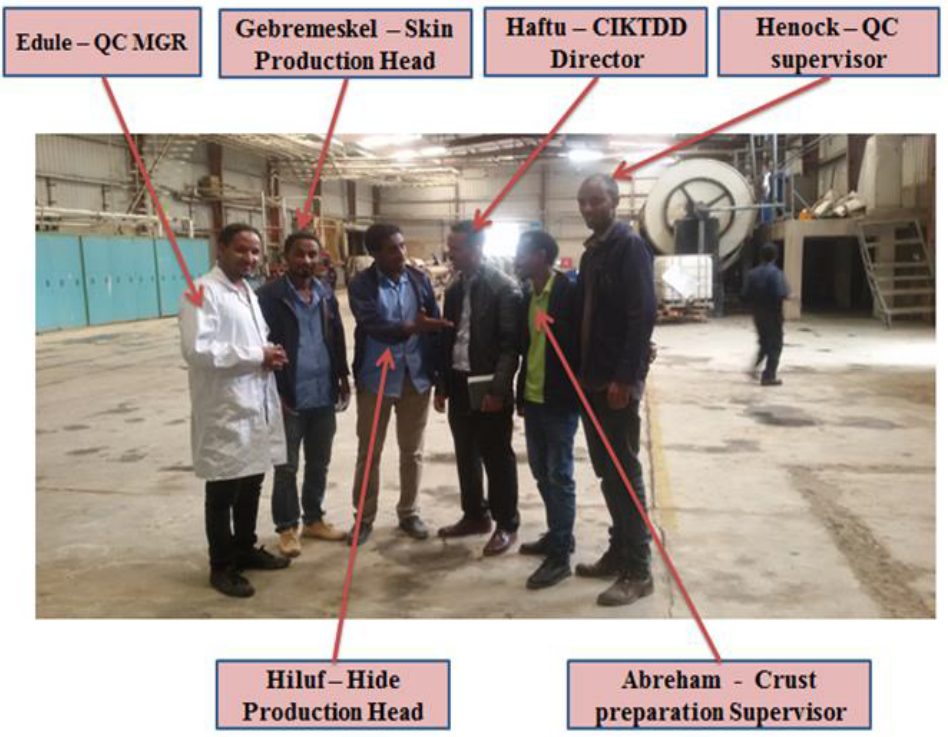

Figure 2: The name of the cross functional team is "change."

\section{Discussion and Results}

\section{Introduction of cross functional team}

The name of the cross functional team is "change." The team comprises 6 members ( 5 male and 1 female). The name of the members starting from left to right. Edul Gegziabeher from QC Manager, Gebremeskel G/Yohannes Birhanefrom skin production, Hiluf from hide production, Haftu Hailu from EKI, Abreham W/rufael from skin crust preparation, Henock Kassahun from skin QC and Alganesh Cherkos from skin finishing. The minimum age is 28 and the maximum age is 37 . The members are from different disciplines of profession (Figure 2).
The overall flow diagram of leather production is sketched in Figure 3 below using process mapping technique. The elliptical, arrow, parabola, rectangle and triangle shapes are demonstrating starting and ending, transportation, operation, inspection and storage respectively.

\section{Theme selection}

Reasons for theme selection: The reason for selecting the problem, at the time of implementing the project, there was high cost because of excessive trimmed and rejected leather.8164 pieces of leather were rejected due to various types of defects which resulted in poor quality. There was also $14,000 \mathrm{~kg}$ of trimmed leather at dry trimming section [1].

Theme selection: In problem selection, the management should focus 
Citation: Hailu H, Tabuchi H, Ezawa H, Jilcha K (2017) Reduction of Excessive Trimming and Reject Leather by Integration of 7 QC Tools and QC Story Formula: The Case Report of Sheba Leather PLC. Ind Eng Manage 6: 223. doi:10.4172/2169-0316.1000223
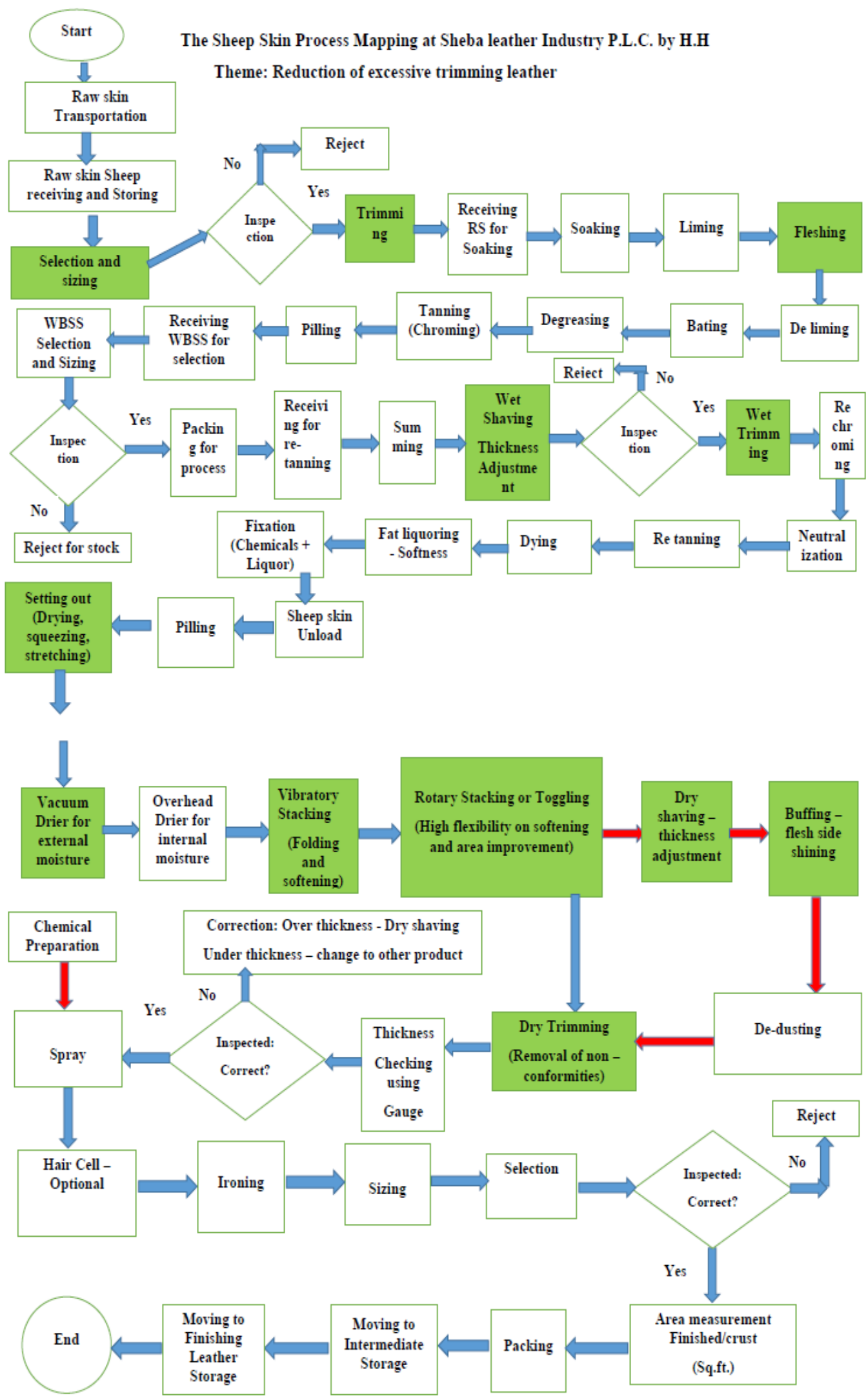

Figure 3: Process flow of leather making in Sheba. 
Citation: Hailu H, Tabuchi H, Ezawa H, Jilcha K (2017) Reduction of Excessive Trimming and Reject Leather by Integration of 7 QC Tools and QC Story Formula: The Case Report of Sheba Leather PLC. Ind Eng Manage 6: 223. doi:10.4172/2169-0316.1000223

Page 4 of 15

on those problems that are interruptions for successful completion of company strategic plan. Based on this, the team evaluated vision, mission, SWOT analysis, challenges. Based on this, Mission of the company is to provide best leather and leather products to the local and international market through maximum utilization of the country hides and skins with continuous generation of wealth to the shareholders thereby contribute its share to the regional and national economy. Vision of the company is "Be branded footwear supplier to the local and international market by 2020 ". The company SWOT is shown as Table 1 below. The management identified 6 main challenges knowledge and skill gap, existing capacity deviation, weak supply process, unequipped product research and development, unable to expand leather goods, weak marketing and sales system. Besides, 21 problems were identified through brainstorming; the critical few are shown in Table 2 below (Table 1 ).

Prioritizing problems: The following judgement criteria's were set to identify theme. These criteria's are management policy-A, urgency-B, effects level-C, Activity period-D, Cross functional-E,
Cause for generated other evils-F, Solved by advance kaizen tools-G and Opportunity for capacity development-H. Simple check sheet containing list of problems and judgement criteria was used to prioritize problems (Table 2).

Theme: Reduction of excessive trimming and rejection leather in skin tannery by following ten steps of Quality Control Story Formula and application of 7 QCQ tools.

\section{Original situation analysis}

Trimming leather for suede upper: In current condition analysis, it is recommended to make problems specific by following the Specific, Measurable, Actionable, Reality and Time constrained - SMART principle. Based on this principle, the project work is more focused on the retanning, crust preparation sections of skin production section of suede upper product type (Table 3).

The table particularized that $14,879.92 \mathrm{~kg}$ is trimmed out from 266,387 pieces of finished leather. Besides, the category and types of

\section{Strength}

\section{Opportunities}

- Modern production set-up equipped with modern machine and equipment which -Incentives and support given to the leather sector by the government of Ethiopia, enables us to produce variety of foot wear styles including mass injection shoes, Having Support -LIDI and EKI, Tax discount for shoe accessories, Proposed free zone good image and dependability in our customers, Young and easily trainable labor, for sale of imported shoe components in Ethiopia, The chance to create synergy Integrated Production set up with flexible machines and equipment to produce variety of with sister companies, Economic growth Ethiopia and other African countries products, Being a member of EFFORT group.

Weakness: High cost operator:

Unable to build reliable supplier and components supply, Un able to build cheapest Component and raw material source, Low productivity, Underutilization of capacity, Unable to produce value adding products, Lack of technical skill and knowledge in both production, Limited skill in design and product development, Low Industrial discipline and working culture, Unable to capture existing market -domestically and internationally.

\section{Long Through put time:}

-Inefficient process, mismatch of production capacities, Weak Supervision of man power and process, Delayed Delivery

Quality of products is not satisfactory:

-Not Standardized bill of material, Problem in inspection in input, process and output,

Limited capacity in product development, Poor customer complaint handling in EU, Increased locally available shoe inputs via increasing FDI, Abundance of cheap labor opp.to international competition, Shifting of the world economy from unipolar to multi-polar expected to create new markets, Growing fashion consciousness globally.

\section{Threats}

Quality deterioration of raw material leather Continuous Foreign Direct Investment in the Ethiopian leather sector, High competition from established international brands and domination of big Chinese companies operating in

US and EU markets, World economic slowdown may affect expected demand, Isolated from capital city, similar industries and suppliers, Substitution of leather Product with cheap synthetic shoes

Table 1: SWOT analysis

\begin{tabular}{|c|c|c|c|c|c|c|c|c|c|c|c|}
\hline \multirow[t]{2}{*}{ Problem } & \multirow[t]{2}{*}{ Theme } & \multicolumn{8}{|c|}{ Judgment criteria } & \multirow[t]{2}{*}{ Score } & \multirow[t]{2}{*}{ Rank } \\
\hline & & A & B & C & D & $\mathbf{E}$ & $\mathbf{F}$ & G & $\mathbf{H}$ & & \\
\hline High cost of product of shoes & Reduction of cost of product & 17 & 20 & 22 & 14 & 20 & 17 & 17 & 16 & 143 & 4 \\
\hline High inventory stock & Reduction of inventory stock & 14 & 17 & 21 & 19 & 14 & 17 & 20 & 17 & 139 & 5 \\
\hline Long delivery time in shoes & Minimizing long delivery time & 19 & 23 & 21 & 22 & 22 & 22 & 21 & 18 & 168 & 1 \\
\hline Low product diversification & Increasing product diversification & 18 & 15 & 19 & 13 & 17 & 16 & 19 & 19 & 136 & 6 \\
\hline Excessive trimming and reject leather & Reduction of trimming and reject leather & 23 & 21 & 20 & 18 & 16 & 17 & 19 & 17 & 151 & 2 \\
\hline Low OEE & Decreasing OEE & 15 & 19 & 19 & 15 & 20 & 16 & 20 & 21 & 145 & 3 \\
\hline
\end{tabular}

Table 2: Problem Judgment Criteria for prioritizing problems.

\begin{tabular}{|c|c|c|c|c|}
\hline \multirow{3}{*}{$\begin{array}{l}\text { S.No. } \\
1 .\end{array}$} & \multirow{3}{*}{\begin{tabular}{|l|} 
Trimming Area \\
Dry Trimming
\end{tabular}} & \multicolumn{2}{|c|}{ Category of Trimming } & \multirow{2}{*}{$\begin{array}{l}\text { Trimmed Weight in } \mathbf{k g} \\
1,012.26 \mathrm{~kg}\end{array}$} \\
\hline & & Abnormal Trim & Trimmer & \\
\hline & & Mechanical trim & Machines-Buffing, Dry Shave & $3,036.8 \mathrm{~kg}$ \\
\hline \multirow[t]{8}{*}{2.} & \multirow[t]{8}{*}{ Final Dry Trimming } & \multirow[t]{7}{*}{ Defect } & Knife cut & $1367.10 \mathrm{~kg}$. \\
\hline & & & Hole & $810.99 \mathrm{~kg}$ \\
\hline & & & Back bone & $509.78 \mathrm{~kg}$ \\
\hline & & & Shape & $451.84 \mathrm{~kg}$ \\
\hline & & & Wound & $115.86 \mathrm{~kg}$ \\
\hline & & & Brand mark & $81.10 \mathrm{~kg}$ \\
\hline & & & Folding & $46.34 \mathrm{~kg}$ \\
\hline & & Mechanical & Buffing & $534 \mathrm{~kg}$ \\
\hline \multirow[t]{2}{*}{3.} & Wet Trimming & Mechanical & Wet shaving & $6,913.86 \mathrm{~kg}$ \\
\hline & & & Grand Total & $14,879.92 \mathrm{~kg}$ \\
\hline
\end{tabular}

Table 3: Trimmed leather weight in $\mathrm{Kg}$ (from 266,387 pieces of leather). 
Citation: Hailu H, Tabuchi H, Ezawa H, Jilcha K (2017) Reduction of Excessive Trimming and Reject Leather by Integration of 7 QC Tools and QC Story Formula: The Case Report of Sheba Leather PLC. Ind Eng Manage 6: 223. doi:10.4172/2169-0316.1000223

Page 5 of 15

defects were also recorded. In order to prioritize the defects, pareto diagram tool were used as shown below (Figure 4).

The above pareto diagram shows that the wet and dry trimming mechanical, knife cut and abnormal trim are $20 \%$ of vital few but eliminating these causes for trimming contributing high effect on trimming; whereas hole, final dry trim mechanical, backbone, shape, wound, brand mark and folding are $80 \%$ of trivial many but contributing less on trimming.

Leather rejection: The skin production section finishing area was the potential area of the cross functional team for identification of types of defects which enables the product to reject. Based on this, 8164 pieces of leather were rejected due to Patchiness - 2558, Wrinkle 1307, Over thickness - 1006, Hair root - 950, Folding - 765, Flesh - 718, Mechanical - 259, Natural defect - 234, Trim - shapely - 169, Under thickness - 92, Sheep in goat - 43, Looseness - 42, Contamination - 20 and Under buff - 1defects (Figure 5).

From the above pareto diagram patchiness, wrinkle, over thickness, hair root and folding are $20 \%$ of vital few defect types which took $80 \%$ of the total rejected pieces of leather. This indicates that eliminating these types defects will results on increasing good quality of leather product. Whereas, flesh, mechanical, natural defect, trim shapely, under thickness, sheep in goat, looseness, contamination and under buff are trivial many defect types that took $20 \%$ of the total rejected pieces of leather [2].

Actual input size (area of leather): From the wet blue selection, the input average area of finished goat lining, upper sued and upper military are 3.32, 3.56 and 4.4 square feet respectively. However, the total average is 3.57 square feet; the upper suede raw got skin input area was 5.96 square feet.

\section{Target Setting}

For this project work, there are three key performance indicators (trimming skin leather, finished skin reject and size increment. According to Katsuya Hosotani: THE QC PROBLEM SOLVING APPROACH - Solving Workplace Problems the Japanese Way book. There are three standards for setting a goal on page 86: The zero, halving and one-third approach. Among these approaches, the halving approach is selected. Based on this, $14,879 \mathrm{~kg}$ of trimmed leather, $5.14 \%$ of finished skin rejects and 2.4 (minus) area of leather will be minimized each by $50 \%$. So, the goal of the project will be reduction of excessive trimming and rejection of leather by $50 \%$ in skin tannery production until august 2016.

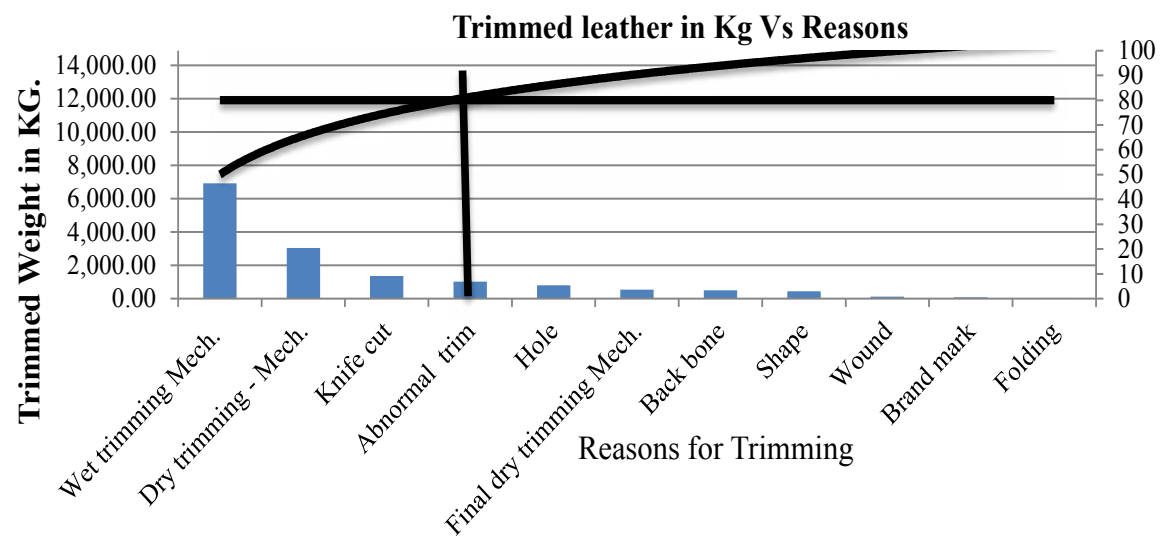

Figure 4: Pareto diagram for trimmed leather.

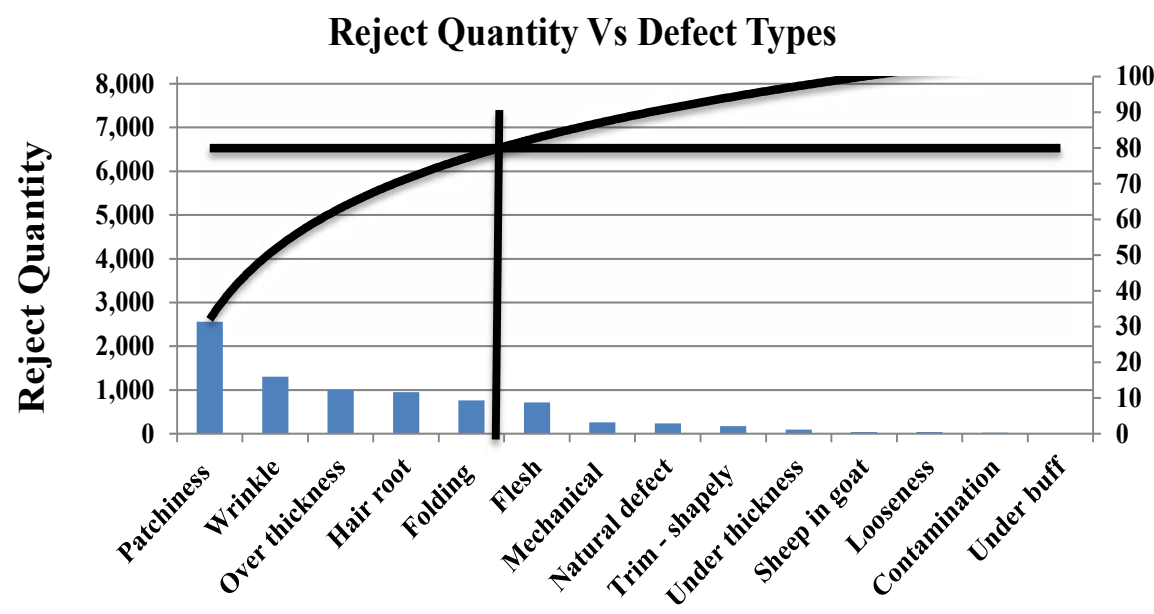

Types of Defect

Figure 5: Pareto diagram for rejected leather. 
Citation: Hailu H, Tabuchi H, Ezawa H, Jilcha K (2017) Reduction of Excessive Trimming and Reject Leather by Integration of 7 QC Tools and QC Story Formula: The Case Report of Sheba Leather PLC. Ind Eng Manage 6: 223. doi:10.4172/2169-0316.1000223

Page 6 of 15

\section{Activity planning and actual activities}

Activity planning: In this step of problem solving approach, An action plan using the $5 \mathrm{~W} 1 \mathrm{H}$ soft techniques was prepared as shown in table below. The objective of the project, activities to be implemented, there place where implementation is going on, responsible personnel for every activities, the time frame and techniques that are going to be applicable are listed on the table (Table 4).

Actual activities: When we compare the activity planning with the actual activities done, the identified counter measures were implemented as per the schedule. The team later agreed on conducting technical training aimed to reduce operator errors. Unfortunately, this counter measure was not implemented due to unavailability of equipped training centre. Meanwhile, the training center took responsibility to facilitate conducting trainings as per the provided skill matrix shown in implementation of the counter measure section of this report (Table 5).

\section{Cause analysis}

In the cause analysis, both fish bone diagram and why - why analysis tools were used. All possible causes for making trimming and rejected leather were listed out using simple brainstorming technique. After listing all possible causes of problem, grouping similar causes have been done in order to identify category of main causes for the problem. After grouping each cause, naming was given for each group. After naming, fish bone diagram was used to show the relationship among all possible grouped causes and main cause. Here, why-why analysis was used to identify possible root causes by discussion. The following two Cause and effect diagrams were prepared for excessive trimming and rejected leather (Figures 6 and 7).

Criteria for selecting critical root causes: The cross functional team members tried to list many root causes using the why - why analysis technique based on data. But, since all root causes are not critical. The team again set selection criteria to identify the true root causes [3-5]. Effect, frequency and controlling were considered to select the critical root causes. Based, the identified critical root causes have been selected as shown in table below (Table 6).

Note: From the table we can understand that based on the three listed criteria's No QC process charts, No SOP, Not Providing Training and No Autonomous Maintenance Standardization and Defective raw skin have got highest score and these root causes have high contribution on excessive trimming and reject leather. Since they are the critical root causes.

\section{Countermeasure examination and implementation}

In determining best solutions it is necessary to consider the following: Feasibility (F): The solutions need to be within the company's resources and schedule; Effectiveness (E): The solutions need to have a reasonable probability of solving the problem; Budget (B): Solution costs must be within the budget of the company and appropriate for the extent of the problem; Employee Involvement (EI): The departments and personnel affected by the problem need to be involved in creating the solution; Focus on Systems (FS): The solutions should be focused on systemic issues; Contingency Planning (CP): All solutions are developed with a certain expectation of success. Based on this, many counter measures have been examined. Herewith below is prepared the table for selected best solutions (Table 7).

Countermeasure implementation action plan 5W1H: After identification of the best counter measures, the cross functional team members were prepared an implementing action plan using $5 \mathrm{~W} 1 \mathrm{H}$ soft technique (Table 8).

Conducting training for skin tannery by skill assessment analysis: During implementation of counter measures, the first activity done was leveling each employee to four by skill matrix. Because, conducting training as per their level has high impact on successful completion of implementation. The traditional way of company's conducting training is providing technical training to all in one class room. But, there was

\begin{tabular}{|c|c|c|c|c|c|c|}
\hline \multirow[t]{2}{*}{ PDCA } & Why? & What? & Where? & Who? & When? & How? \\
\hline & Objective & Items to be implemented & Location & Person in charge & Dec 2015-Aug 2016 & Method \\
\hline \multirow[t]{9}{*}{ Plan } & \multirow{3}{*}{$\begin{array}{l}\text { Impression, } \\
\text { Awareness creation }\end{array}$} & 1st day: Kick-off (1-2 hrs), & Manage. hall & EKI Consultant & December 07 & Discussion \\
\hline & & $\begin{array}{l}\text { 2nd day:Training for management } \\
\text { ( } 6 \mathrm{hrs})\end{array}$ & Employee hall & EKI Consultant & December 08 & CRT \\
\hline & & Confirm company policy & Manage. hall & Top Management & Dec 09-Dec 11 & Cross SWOT \\
\hline & Set up issues & Subject selection & Skin Tannery & Management & Dec 14-Dec 18 & Selection matrix \\
\hline & Capacity building & Training for A-KPT & Skin Tannery & EKI Consultant & Dec 21-Jan 01 & CRT and ICT \\
\hline & Examine & Comprehending the current situation & Skin Tannery & CFT, EKI Consultant & Jan 04-Jan 15 & Process map, Pareto Diagram \\
\hline & & Progress sharing meeting & EKI & EKI Consultant & Jan 18-Jan 29 & \\
\hline & Goal setting & Goal setting & Skin Tannery & CFT, EKI Consultant & Feb 01 and Feb 02 & $\begin{array}{l}\text { The halving approach, line } \\
\text { graph }\end{array}$ \\
\hline & Collect information & Activity planning & Skin Tannery & CFT, EKI Consultant & Feb 03-Feb 05 & 5W1H, Gantt Chart \\
\hline \multirow[t]{5}{*}{ Do } & Identify problems & Cause analysis & Skin Tannery & CFT, EKI Consultant & Feb 08-Mar 11 & Fishbone Diagram, 5Whys \\
\hline & & Progress sharing meeting & EKI & EKI Consultant & Mar 14-Mar 25 & \\
\hline & $\begin{array}{l}\text { Examine and List } \\
\text { solutions }\end{array}$ & Examine counter measures & Skin Tannery & CFT, EKI Consultant & Mar 28 - Apr 06 & Judgment criteria, Likert scale \\
\hline & Implement measures & Implement counter measures & Skin Tannery & CFT, EKI Consultant & Apr 07-July 01 & $5 \mathrm{~W} 1 \mathrm{H}$ \\
\hline & & Progress sharing meeting & EKI & EKI Consultant & July 04-July 15 & \\
\hline Check & Confirm & Comprehending result & Skin Tannery & CFT, EKI Consultant & July 18 -July 29 & Line graph, Pareto Diagram \\
\hline \multirow[t]{4}{*}{ Act } & \multirow[t]{4}{*}{ Follow up progress } & Standardization and training & Skin Tannery & CFT, EKI Consultant & Aug 8 and Aug 9 & 5W1H, Control chart, SOP \\
\hline & & Review of future issue & Skin Tannery & CFT & August 10 & $\begin{array}{l}\text { Communication Review } \\
\text { meeting }\end{array}$ \\
\hline & & Report to managements of ICT & Manage. hall & EKI Consultant & August 11 & \\
\hline & & Final presentation in EKI & EKI & EKI Consultant & Aug 22-Aug 26 & \\
\hline
\end{tabular}

Table 4: Activity planning for the project. 
Citation: Hailu H, Tabuchi H, Ezawa H, Jilcha K (2017) Reduction of Excessive Trimming and Reject Leather by Integration of 7 QC Tools and QC Story Formula: The Case Report of Sheba Leather PLC. Ind Eng Manage 6: 223. doi:10.4172/2169-0316.1000223

\begin{tabular}{|c|c|c|c|c|c|c|c|c|c|c|c|c|}
\hline \multirow[t]{2}{*}{ PDCA } & \multirow{2}{*}{\multicolumn{2}{|c|}{$\begin{array}{l}\text { What? } \\
\text { Items to be Implemented }\end{array}$}} & & \multicolumn{9}{|c|}{ When? } \\
\hline & & & & Dec. & Jan. & Feb. & Mar & Apr. & May & Jun. & Jul. & Aug. \\
\hline \multirow[t]{16}{*}{ Plan } & \multirow{2}{*}{\multicolumn{2}{|c|}{ 1st day: Kick-off (1-2hrs), }} & Plan & $\rightarrow$ & & & & & & & & \\
\hline & & & Actual & $\rightarrow$ & & & & & & & & \\
\hline & \multirow{2}{*}{\multicolumn{2}{|c|}{ 2nd day: Training for management (6hrs) }} & Plan & $\rightarrow$ & & & & & & & & \\
\hline & & & Actual & $\rightarrow$ & & & & & & & & \\
\hline & \multirow{2}{*}{\multicolumn{2}{|c|}{ Confirm company policy }} & Plan & $\rightarrow$ & & & & & & & & \\
\hline & & & Actual & $\rightarrow$ & & & & & & & & \\
\hline & \multirow{2}{*}{\multicolumn{2}{|c|}{ Subject selection }} & Plan & $\rightarrow$ & & & & & & & & \\
\hline & & & Actual & $\rightarrow$ & & & & & & & & \\
\hline & \multirow{2}{*}{\multicolumn{2}{|c|}{ Training for A-KPT }} & Plan & & $\rightarrow$ & & & & & & & \\
\hline & & & Actual & & $\rightarrow$ & & & & & & & \\
\hline & \multirow{2}{*}{\multicolumn{2}{|c|}{ Comprehending the current situation }} & Plan & & $\rightarrow$ & & & & & & & \\
\hline & & & Actual & & $\rightarrow$ & & & & & & & \\
\hline & \multirow{2}{*}{\multicolumn{2}{|c|}{ Goal setting }} & Plan & & & $\rightarrow$ & & & & & & \\
\hline & & & Actual & & & $\rightarrow$ & & & & & & \\
\hline & \multirow{2}{*}{\multicolumn{2}{|c|}{ Activity planning }} & Plan & & & $\rightarrow$ & & & & & & \\
\hline & & & Actual & & & $\rightarrow$ & & & & & & \\
\hline \multirow[t]{16}{*}{ Do } & \multirow{2}{*}{\multicolumn{2}{|c|}{ Cause analysis }} & Plan & & & $\rightarrow$ & & & & & & \\
\hline & & & Actual & & & $\rightarrow$ & & & & & & \\
\hline & \multirow{2}{*}{\multicolumn{2}{|c|}{ Examine counter measures }} & Plan & & & & $\rightarrow$ & & & & & \\
\hline & & & Actual & & & & $\rightarrow$ & & & & & \\
\hline & \multirow{12}{*}{$\begin{array}{l}\text { Implement } \\
\text { counter } \\
\text { measures }\end{array}$} & \multirow[t]{2}{*}{ Providing Technical Training } & Plan & & & & & & & & & \\
\hline & & & Actual & & & & & & & & & \\
\hline & & \multirow[t]{2}{*}{ Prep. and Implementation of SOP } & Plan & & & & & \multicolumn{3}{|l|}{$\rightarrow$} & & \\
\hline & & & Actual & & & & & \multicolumn{3}{|l|}{$\rightarrow$} & & \\
\hline & & \multirow{2}{*}{$\begin{array}{l}\text { Prep. and Implementation of Four basic } \\
\text { AM activities }\end{array}$} & Plan & & & & & \multicolumn{3}{|l|}{$\rightarrow$} & & \\
\hline & & & Actual & & & & & & & \\
\hline & & Prep. and Implementation of QC Process & Plan & & & & & $\rightarrow$ & & & & \\
\hline & & Chart & Actual & & & & & $\rightarrow$ & & & & \\
\hline & & Performing Skill analysis & Plan & & & & & $\rightarrow$ & & & & \\
\hline & & & Actual & & & & & $\rightarrow$ & & & & \\
\hline & & $100 \%$ Raw skin inspection & Plan & & & & & $\rightarrow$ & & & & \\
\hline & & & Actual & & & & & $\rightarrow$ & & & & \\
\hline Check & Comprehen & result & Plan & & & & & & & & $\rightarrow$ & \\
\hline & & & Actual & & & & & & & & $\rightarrow$ & \\
\hline Act & Standardiza & and training & Plan & & & & & & & & & $\rightarrow$ \\
\hline & & & Actual & & & & & & & & & $\rightarrow$ \\
\hline & Review of $f$ & issue & Plan & & & & & & & & & $\rightarrow$ \\
\hline & & & Actual & & & & & & & & & $\rightarrow$ \\
\hline
\end{tabular}

Table 5: Actual activities done during in company training

operator's performance evaluation criteria's. The team discussed on these parameters and agreed to used them for categorizing each operators: Production quantity output per day, Quality of the product - as per the customer requirement, Cost reduction - by eliminating rework, reject, Material handling at workplace, Self - discipline regarding to behavioral changes, Usage of PPE - Personnel Protective Equipment, Implementation of 5 S activities, Synergy - interaction with the group, leader, Sense of ownership, Creating new ideas (Table 9 and Figure 8).

The above pie chart elaborates $52.67 \%$ of the operators are inexperience, since they are new comers; $42 \%$ of operators are dependent and still they need serious follow up from their leaders forman and supervisors. Only $5.33 \%$ of operators are independent, they can work alone but could not instruct to others. This analysis also shows that above $50 \%$ of operators are inexperience and dependent. They have low skill and knowledge regarding to their working procedures, processes and machines. Obviously, providing on job technical training (since there is no training center) as per their working areas to fill their skill gaps is unquestionable. Even though, there are no operators who can instruct for others, Quality manager in collaboration with cross functional team members, they conducted technical training regarding to trimming, adjustment, inspection, feeding system, standardized operating procedure for each process and machines, autonomous maintenance, application of QC process chart (Table 10).

Four basic autonomous maintenance activities like inspection, cleaning, oiling and bolt tightening for beam house, retanning and crust preparation section of skin tannery machines is prepared and awareness was created by cross functional team members in collaboration with QC Manager (Table 11 and Figure 9).

Quality control process chart for beam house, retanning and crust preparation section of skin tannery quality in stations is prepared and awareness was created by QC Manager in collaboration with cross functional team members (Table 12). 
Citation: Hailu H, Tabuchi H, Ezawa H, Jilcha K (2017) Reduction of Excessive Trimming and Reject Leather by Integration of 7 QC Tools and QC

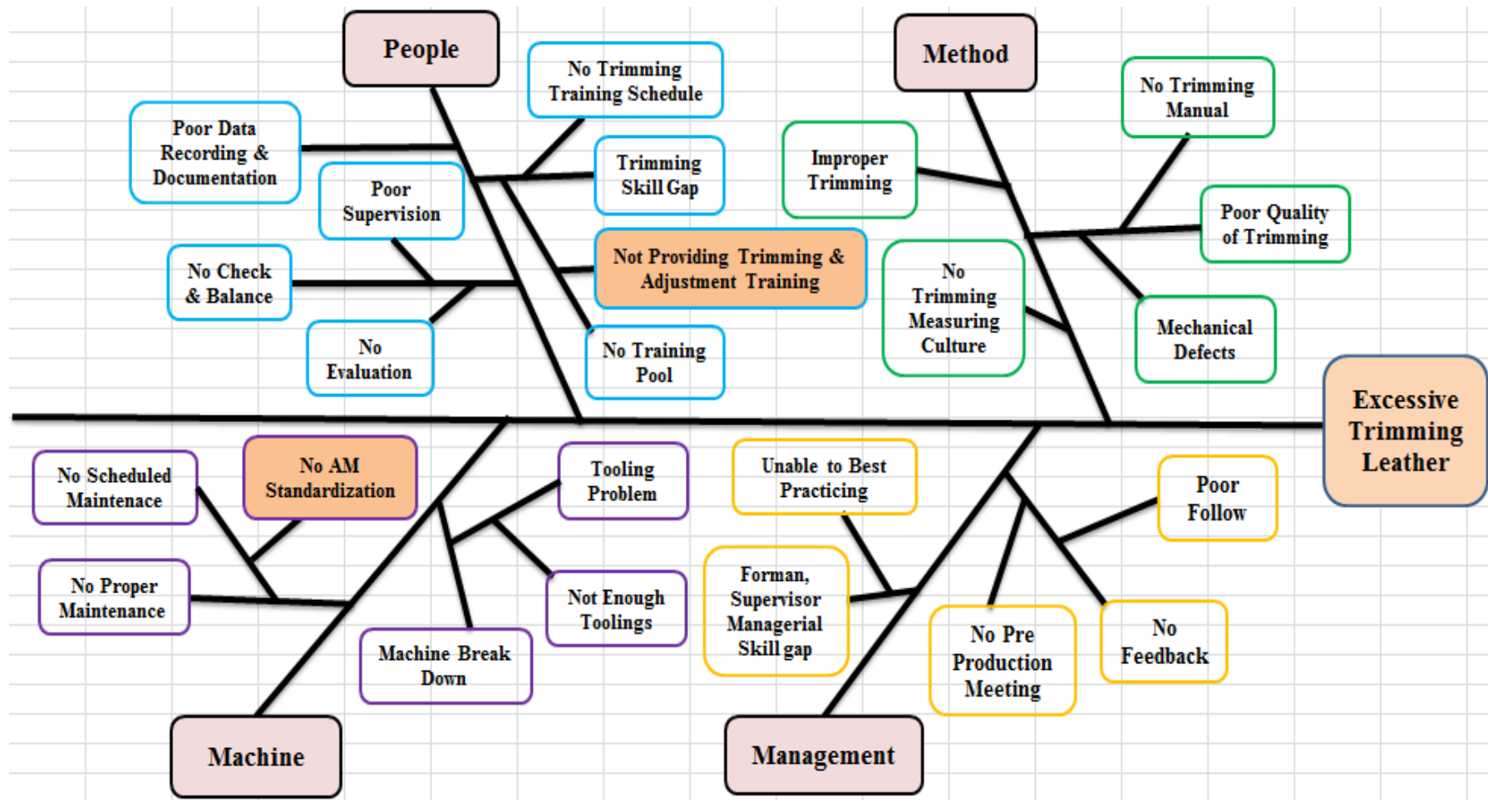

Figure 6: Fish bone diagram for excessive trimming leather.

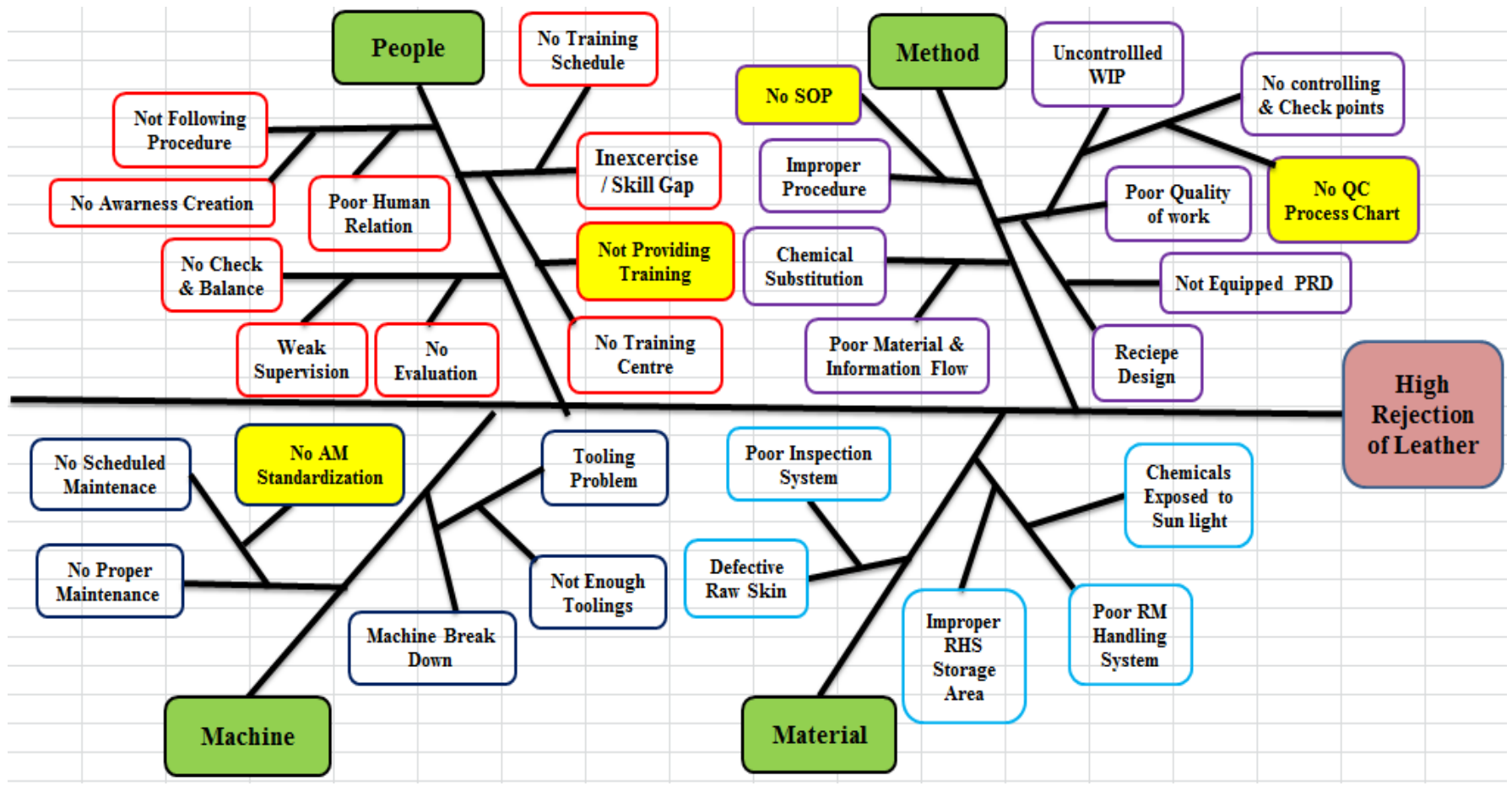

Figure 7: Fish bone diagram for high rejection of leather. 
Citation: Hailu H, Tabuchi H, Ezawa H, Jilcha K (2017) Reduction of Excessive Trimming and Reject Leather by Integration of 7 QC Tools and QC Story Formula: The Case Report of Sheba Leather PLC. Ind Eng Manage 6: 223. doi:10.4172/2169-0316.1000223

Page 9 of 15

\begin{tabular}{|c|c|c|c|c|}
\hline \multirow[t]{2}{*}{ Potential Causes } & \multicolumn{3}{|c|}{ Criteria } & \multirow[t]{2}{*}{ Score } \\
\hline & Effect & Freq. & Control & \\
\hline \multicolumn{5}{|l|}{ Method } \\
\hline Uncontrolled WIP & 9 & 7 & 8 & 504 \\
\hline No controlling and Check points & 10 & 8 & 6 & 480 \\
\hline Poor Quality of work & 10 & 6 & 4 & 240 \\
\hline No QC Process Chart & 10 & 10 & 10 & 1000 \\
\hline Not Equipped PRD & 8 & 8 & 5 & 320 \\
\hline Recipe Design & 10 & 8 & 5 & 400 \\
\hline Poor Material and Information Flow & 10 & 9 & 7 & 630 \\
\hline Chemical Substitution & 9 & 7 & 6 & 378 \\
\hline No S.O.Procedure & 10 & 10 & 10 & 1000 \\
\hline Improper Procedure & 9 & 8 & 6 & 432 \\
\hline \multicolumn{5}{|l|}{ People } \\
\hline No Training Schedule & 8 & 9 & 8 & 576 \\
\hline Inexcercise / Skill Gap & 10 & 10 & 7 & 700 \\
\hline Not Providing Training & 10 & 10 & 10 & 1000 \\
\hline No Training Centre & 10 & 10 & 6 & 600 \\
\hline No Performance Evaluation & 8 & 9 & 6 & 432 \\
\hline Weak Supervision & 9 & 10 & 6 & 540 \\
\hline No Check and Balance & 10 & 8 & 5 & 400 \\
\hline No Awareness Creation & 8 & 8 & 10 & 640 \\
\hline Poor Human Relation & 8 & 7 & 8 & 448 \\
\hline Not Following Procedure & 10 & 6 & 6 & 360 \\
\hline \multicolumn{5}{|l|}{ Machine } \\
\hline Machine Break Down & 10 & 6 & 8 & 480 \\
\hline Not Enough Tooling's & 8 & 7 & 9 & 504 \\
\hline Tooling Problem & 8 & 7 & 10 & 560 \\
\hline No Proper Maintenance & 9 & 6 & 10 & 540 \\
\hline No AM Standardization & 10 & 10 & 10 & 1000 \\
\hline No Scheduled Maintenance & 7 & 6 & 10 & 420 \\
\hline \multicolumn{5}{|l|}{ Material } \\
\hline Poor RM Inspection System & 10 & 8 & 6 & 480 \\
\hline Defective Raw Skin & 10 & 10 & 9 & 900 \\
\hline Improper RHS Storage Area & 8 & 8 & 6 & 384 \\
\hline Poor RM Handling System & 9 & 7 & 6 & 378 \\
\hline Chemicals Exposed to Sun light & 7 & 8 & 6 & 336 \\
\hline
\end{tabular}

Table 6: Critical root causes selection.

\begin{tabular}{|c|c|c|c|c|}
\hline Theme & Problem & Facts & Counter measure & Judgment \\
\hline \multirow[b]{4}{*}{$\begin{array}{l}\text { Excessive } \\
\text { Trimming }\end{array}$} & $\begin{array}{l}\text { Wet trimming } \\
\text { Mechanical }\end{array}$ & Not providing adjustment training & $\begin{array}{l}\text { First by established training room with skilled trainer and } \\
\text { equipment, then providing technical adjustment training }\end{array}$ & Excellent \\
\hline & $\begin{array}{l}\text { Dry trimming - } \\
\text { Mechanical }\end{array}$ & Not standardized AM four basic activities & $\begin{array}{l}\text { Preparation of standardized four basic AM activities - } \\
\text { Inspection, Cleaning, Lubrication (oil), bolt tightening }\end{array}$ & Excellent \\
\hline & Knife cut & Selector passes defects like Knife cut & Providing technical training to raw skin selectors & Excellent \\
\hline & Abnormal trim & Unskilled trimmer & $\begin{array}{l}\text { Preparation of trimming manual and providing technical } \\
\text { trimming training to trimmers }\end{array}$ & Excellent \\
\hline \multirow{6}{*}{$\begin{array}{l}\text { High } \\
\text { Rejection }\end{array}$} & Patchiness & $\begin{array}{l}\text { Not standardized recipe and operating } \\
\text { procedure }\end{array}$ & $\begin{array}{l}\text { Preparation of standardized recipe design, operating procedure } \\
\text { and QC process chart for re tanning drum }\end{array}$ & Excellent \\
\hline & Wrinkle & $\begin{array}{l}\text { Not standardized recipe and operating } \\
\text { procedure }\end{array}$ & $\begin{array}{l}\text { Preparation of standardized recipe design, operating procedure } \\
\text { and QC process chart for re tanning drum }\end{array}$ & Excellent \\
\hline & \multirow[t]{2}{*}{ Over thickness } & \multirow[t]{2}{*}{ No training provided on adjustment } & $\begin{array}{l}\text { Providing technical training to wet and dry shaving machine } \\
\text { operators }\end{array}$ & Excellent \\
\hline & & & $\begin{array}{l}\text { Preparation of standardized inspection, cleaning, lubrication } \\
\text { (oil), bolt tightening for wet and }\end{array}$ & Excellent \\
\hline & Hair root & Chemical painting problem & Preparation of painting manual and providing training & Excellent \\
\hline & Folding & Poor loading and unloading & $\begin{array}{l}\text { Providing technical loading and unloading training to } \\
\text { dry shaving, buffing, rotary, vibratory, Sam setting } \\
\text { machine operators }\end{array}$ & Excellent \\
\hline
\end{tabular}

Table 7: Counter measures Examination. 
Citation: Hailu H, Tabuchi H, Ezawa H, Jilcha K (2017) Reduction of Excessive Trimming and Reject Leather by Integration of 7 QC Tools and QC Story Formula: The Case Report of Sheba Leather PLC. Ind Eng Manage 6: 223. doi:10.4172/2169-0316.1000223

Page 10 of 15

\begin{tabular}{|c|c|c|c|c|c|c|c|c|c|c|c|}
\hline \multirow{3}{*}{$\begin{array}{l}\text { Reasons for } \\
\text { trimming and } \\
\text { Rejection }\end{array}$} & \multirow{3}{*}{$\begin{array}{l}\text { WHAT? } \\
\text { Problem }\end{array}$} & \multirow{3}{*}{$\begin{array}{l}\text { WHERE? } \\
\text { Location }\end{array}$} & \multirow{3}{*}{$\begin{array}{c}\text { HOW? } \\
\begin{array}{c}\text { Recommended } \\
\text { action }\end{array}\end{array}$} & \multicolumn{6}{|c|}{ WHEN? } & \multirow{3}{*}{$\begin{array}{l}\text { WHO? } \\
\begin{array}{c}\text { Person in } \\
\text { charge }\end{array}\end{array}$} & \multirow{3}{*}{$\begin{array}{c}\text { WHY? } \\
\text { Objective }\end{array}$} \\
\hline & & & & \multicolumn{6}{|c|}{ Duration April 11-May 27/2016 } & & \\
\hline & & & & $18-22$ & $25-28$ & 02-06 & $09-13$ & $16-20$ & 23-27 & & \\
\hline $\begin{array}{l}\text { Wet trimming } \\
\text { mechanical }\end{array}$ & $\begin{array}{l}\text { Not providing } \\
\text { adjustment training }\end{array}$ & $\begin{array}{l}\text { Wet shaving } \\
\text { machine }\end{array}$ & Adjustment training & $\rightarrow$ & & & & & & $\begin{array}{l}\text { Retanning } \\
\text { supervisor, } \\
\text { CFT }\end{array}$ & $\begin{array}{l}\text { To prevent } \\
\text { mechanical } \\
\text { defect }\end{array}$ \\
\hline $\begin{array}{l}\text { Dry trim. } \\
\text { mechanical }\end{array}$ & $\begin{array}{l}\text { Not standardized } \\
\text { four basic AM } \\
\text { activities }\end{array}$ & $\begin{array}{l}\text { Dry shaving and } \\
\text { buffing }\end{array}$ & Standardized ICOBT & & $\rightarrow$ & & & & & $\begin{array}{l}\text { CFT, Skin } \\
\text { maintenance }\end{array}$ & \\
\hline Knife cut & $\begin{array}{l}\text { Selector checking } \\
\text { problem }\end{array}$ & Raw skin store & $\begin{array}{l}\text { Training, 100\% } \\
\text { inspection }\end{array}$ & & & $\rightarrow$ & & & & $\begin{array}{l}\text { QC manager, } \\
\text { CFT }\end{array}$ & $\begin{array}{l}\text { To prevent } \\
\text { passing defect }\end{array}$ \\
\hline Abnormal trim & Unskilled trimmer & $\begin{array}{l}\text { Wet and dry } \\
\text { trimming }\end{array}$ & $\begin{array}{l}\text { technical training } \\
\text { (How to trim) }\end{array}$ & & & $\rightarrow$ & & & & CFT & $\begin{array}{l}\text { To increase } \\
\text { area of leather }\end{array}$ \\
\hline Patchiness & $\begin{array}{l}\text { Not following the } \\
\text { Procedure }\end{array}$ & Retanning drum & $\begin{array}{l}\text { SOP, QC Process } \\
\text { chart }\end{array}$ & & & & & & & $\begin{array}{l}\text { supervisor, } \\
\text { CFT }\end{array}$ & $\begin{array}{l}\text { To increase } \\
\text { leather } \\
\text { evenness }\end{array}$ \\
\hline Wrinkle & $\begin{array}{l}\text { Not following the } \\
\text { Procedure }\end{array}$ & $\begin{array}{l}\text { Beam house - } \\
\text { Tanning drum }\end{array}$ & $\begin{array}{l}\text { SOP, QC process } \\
\text { chart }\end{array}$ & & & & $\rightarrow$ & & & $\begin{array}{l}\text { supervisor, } \\
\text { CFT }\end{array}$ & $\begin{array}{l}\text { To prevent } \\
\text { crease }\end{array}$ \\
\hline Over thickness & Adjustment & $\begin{array}{l}\text { Buffing, Wet and } \\
\text { Dry shaving }\end{array}$ & Training & & & & & & & $\begin{array}{l}\text { supervisor, } \\
\text { CFT }\end{array}$ & $\begin{array}{l}\text { To prevent } \\
\text { defect }\end{array}$ \\
\hline Hair root & $\begin{array}{l}\text { Painting - } \\
\text { procedure }\end{array}$ & $\begin{array}{l}\text { Beam house - } \\
\text { Tanning }\end{array}$ & $\begin{array}{l}\text { SOP, QC process } \\
\text { chart }\end{array}$ & & & & & $\rightarrow$ & & $\begin{array}{l}\text { supervisor, } \\
\text { CFT }\end{array}$ & $\begin{array}{l}\text { To eliminate } \\
\text { the hair on } \\
\text { grain }\end{array}$ \\
\hline Folding & $\begin{array}{l}\text { Poor feeding } \\
\text { system }\end{array}$ & Setting out & Training & & & & & & $\rightarrow$ & $\begin{array}{l}\text { Skin } \\
\text { production }\end{array}$ & $\begin{array}{l}\text { To prevent } \\
\text { damaged }\end{array}$ \\
\hline
\end{tabular}

Table 8: Counter measures implementation action plan.

\begin{tabular}{|c|c|c|c|c|c|}
\hline \multirow[t]{2}{*}{ S.NO. } & \multirow[t]{2}{*}{ Section } & \multicolumn{4}{|c|}{ Level of operators } \\
\hline & & $\begin{array}{c}\text { Level-1 } \\
\text { (Inexperience) }\end{array}$ & $\begin{array}{c}\text { Level-2 } \\
\text { (Dependent) }\end{array}$ & $\begin{array}{c}\text { Level-3 } \\
\text { (Independent) }\end{array}$ & $\begin{array}{c}\text { Level-4 } \\
\text { (Able to instruct) }\end{array}$ \\
\hline & RHS Store & 4 & 2 & - & - \\
\hline & Skin Beam House & 7 & 15 & 3 & - \\
\hline & Skin Wet Blue Selection & 3 & 11 & - & - \\
\hline & Skin retanning & 31 & 2 & - & - \\
\hline & Crust preparation & 27 & 19 & 1 & - \\
\hline & Total Quality Control & - & 3 & 2 & - \\
\hline & Finishing & 7 & 11 & 2 & - \\
\hline & Total & 79 & 63 & 8 & - \\
\hline & 150 & $52.67 \%$ & $42 \%$ & $5.33 \%$ & \\
\hline
\end{tabular}

Table 9: Level of operators.

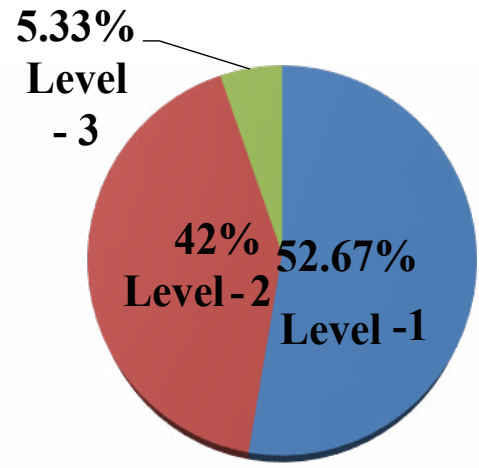

Figure 8: Pie chart for level of operators. 
Citation: Hailu H, Tabuchi H, Ezawa H, Jilcha K (2017) Reduction of Excessive Trimming and Reject Leather by Integration of 7 QC Tools and QC Story Formula: The Case Report of Sheba Leather PLC. Ind Eng Manage 6: 223. doi:10.4172/2169-0316.1000223

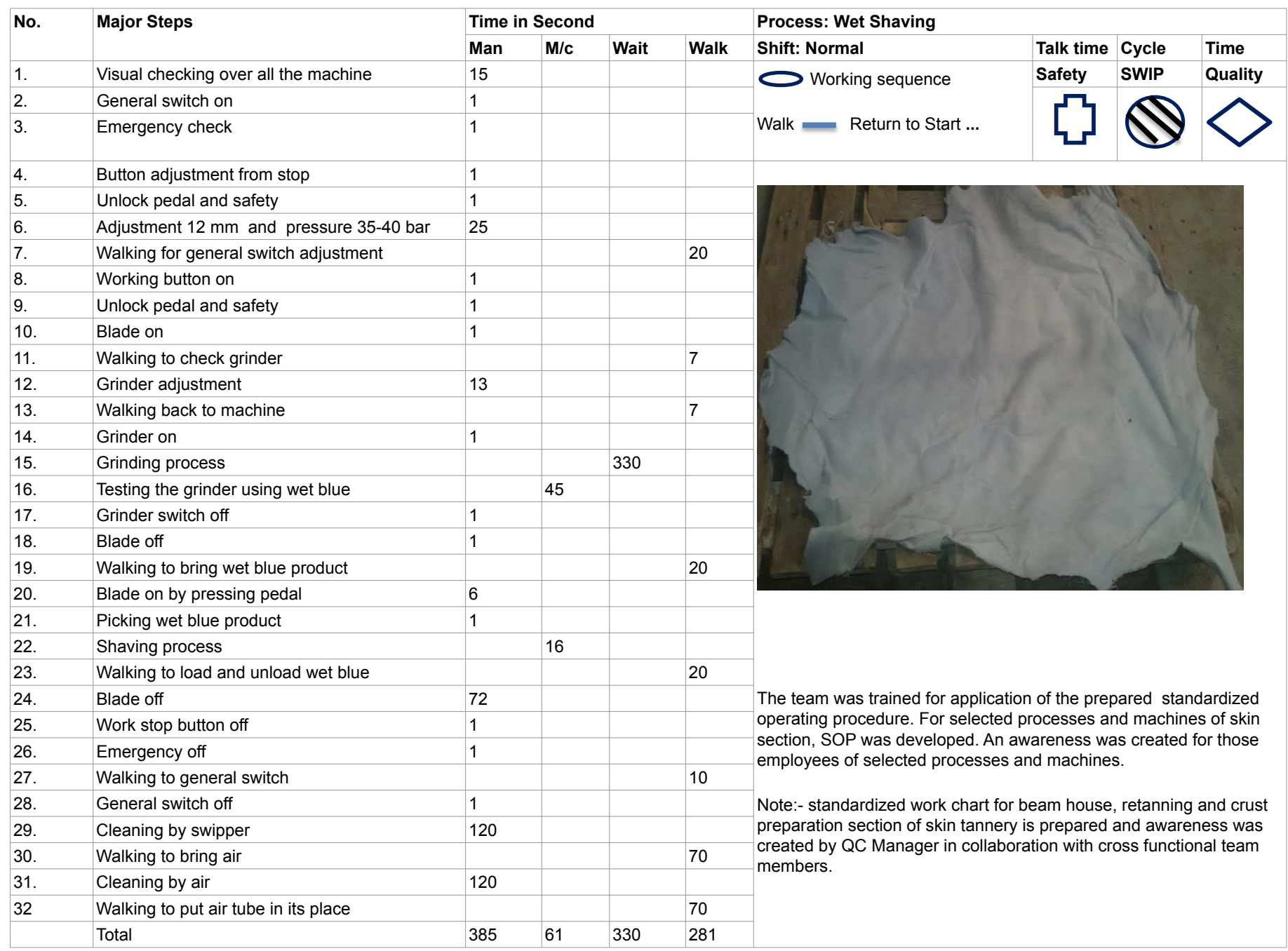

Table 10: Standardized work chart - SOP.

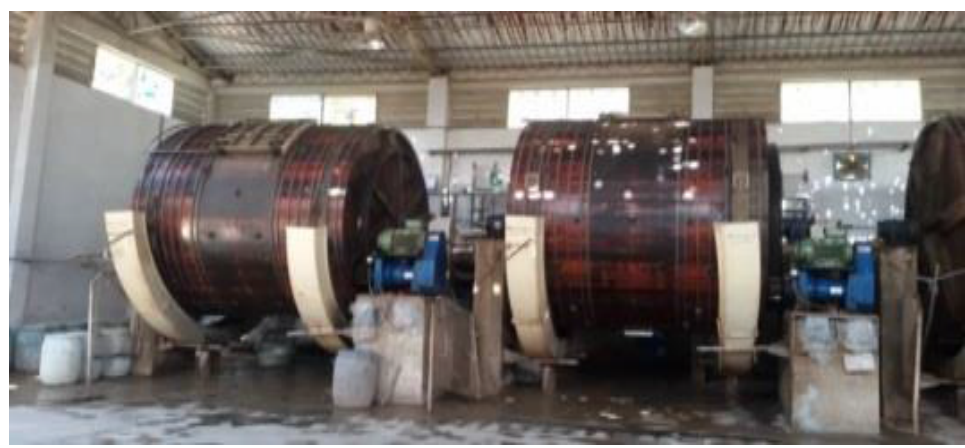

Figure 9: Beam house.

\section{Comprehending the results}

The cross functional team members were evaluating the implementation in order to confirming whether the implemented countermeasures have resulted in achieving quantitative and qualitative results for both trimming and rejected leather. Obviously, it is known that when there is less trimming, the size of the leather will remain as it is. There is no opportunity to reduce from one size to another. Based on the evaluation the result is shown below (Table 13).

Discussion on the table: The total trimmed leather weight before implementing the counter measures from 266,387 pcs were $14,879.92$ $\mathrm{kg}$. But, after implementation the counter measures the total trimmed leather became $8,524 \mathrm{~kg}$. In sampling, it is possible to use both vary and 
Citation: Hailu H, Tabuchi H, Ezawa H, Jilcha K (2017) Reduction of Excessive Trimming and Reject Leather by Integration of 7 QC Tools and QC Story Formula: The Case Report of Sheba Leather PLC. Ind Eng Manage 6: 223. doi:10.4172/2169-0316.1000223

Page 12 of 15

\begin{tabular}{|c|c|c|c|c|c|}
\hline \multicolumn{2}{|c|}{ Department: Tannery Skin Production } & \multirow{2}{*}{\multicolumn{2}{|c|}{ Section: Beam House }} & \multicolumn{2}{|c|}{ Machine: Drum } \\
\hline \multicolumn{5}{|c|}{ Standards for Drum - Cleaning } & \\
\hline S.No. & Part of M/c - Location & Method of cleaning & Standard & Time & Frequency \\
\hline 1. & Crown & \multicolumn{2}{|l|}{ Rag } & $10 \mathrm{~min}$ & Weekly \\
\hline 2. & Pinon & \multicolumn{2}{|l|}{ Rag } & $10 \mathrm{~min}$ & Weekly \\
\hline 3. & Gear box & Rag & Shine & $10 \mathrm{~min}$ & Weekly \\
\hline 4. & Bearing house & Rag & Shine & $10 \mathrm{~min}$ & Weekly \\
\hline 5. & Drum body & Oil & Shine & $30 \mathrm{~min}$ & Monthly \\
\hline 6. & Gear box motor & Air and Rag & Shine & $15 \mathrm{~min}$ & Monthly \\
\hline 7. & Electrical board & Rag and emery, paper & Shine & $30 \mathrm{~min}$ & Monthly \\
\hline 8. & Electrical panel & Rag & Shine & $5 \mathrm{~min}$ & Monthly \\
\hline 9. & Filter & Water & Shine & $6 \mathrm{hr}$. & $6^{\text {th }}$ per month \\
\hline \multicolumn{6}{|c|}{ Standards for Drum - Inspection } \\
\hline 1. & Drum wood & Visual & Rotation & $2 \min$ & Daily \\
\hline 2. & Pinion & Sound & Functional & $1 \mathrm{~min}$ & Daily \\
\hline 3. & Crown & Visual & Functional & $2 \min$ & Daily \\
\hline 4. & Gear box & Touching & Vibration & $5 \min$ & Daily \\
\hline 5. & Motor & Visual & Functional & $2 \min$ & Daily \\
\hline 6. & Banyan & Visual & Functional & $1 \mathrm{~min}$ & Daily \\
\hline 7. & Darning valve & Visual & No leakage & $1 \mathrm{~min}$ & Daily \\
\hline 8. & Drum door & Visual & Functional & $2 \min$ & Daily \\
\hline 9. & $V$ - belt & Visual & Functional & $3 \mathrm{~min}$ & Monthly \\
\hline Standa & for Drum - Lubrication & & & & \\
\hline 1. & Crown & Manual by hand & EP3 & $1.2 \mathrm{~kg}$ & $6^{\text {th }}$ per month \\
\hline 2. & Pinion & Manual by hand & EP3 & $1.2 \mathrm{~kg}$ & $6^{\text {th }}$ per month \\
\hline 3. & Buranz - bushe & Manual pump & EP3 & $1.2 \mathrm{~kg}$ & Weekly \\
\hline 4. & Berak - fliud & Manual by hand & (Oil HBF 4) & 0.5 Liter & Once per 2 year \\
\hline Standa & for Drum - Bolt tightening & & & & \\
\hline 1. & Foundation bolt & Wrench & Lock & 04 & When vibration \\
\hline 2. & Gear box foundation bolt & Wrench & Lock & 08 & When vibration \\
\hline 3. & Motor support & By hand & Lock & 01 & When down \\
\hline 4. & Drum door bolt & Wrench & Lock & 04 & When rearrange water \\
\hline 5. & Drum hop & Wrench & Lock & 06 & $6^{\text {th }}$ per monthly \\
\hline 6. & Electrical board bolt & Screw & Lock & 20 & Monthly \\
\hline
\end{tabular}

Table 11: Four basic autonomous maintenance activities.

\begin{tabular}{|c|c|c|c|c|c|c|c|c|c|c|}
\hline & \multirow{3}{*}{\begin{tabular}{|l} 
Product \\
name
\end{tabular}} & & \multirow{2}{*}{\begin{tabular}{|l|} 
Plant concerned \\
Section
\end{tabular}} & Sheba & \multirow{2}{*}{$\begin{array}{l}\text { Doc. } \\
\text { number }\end{array}$} & \multirow[t]{2}{*}{ D-01 } & & \multirow{5}{*}{ Remarks } \\
\hline \multicolumn{3}{|c|}{ QC Process Chart } & & & & $\begin{array}{l}\text { Tannery } \\
\text { production }\end{array}$ & & & & \\
\hline Department & \multicolumn{2}{|c|}{ RHS Store } & & & Line concerned & & Date & & & \\
\hline \multirow{2}{*}{$\begin{array}{l}\text { Process } \\
\text { number }\end{array}$} & \multirow{2}{*}{$\begin{array}{l}\text { Process } \\
\text { name }\end{array}$} & \multirow{2}{*}{$\begin{array}{l}\text { Facility } \\
\text { name or } \\
\text { input }\end{array}$} & \multirow{2}{*}{$\begin{array}{l}\text { Specific } \\
\text { Working area }\end{array}$} & \multicolumn{2}{|l|}{ Control Point } & \multicolumn{4}{|c|}{ Control method } & \\
\hline & & & & $\begin{array}{l}\text { Processing } \\
\text { condition }\end{array}$ & $\begin{array}{l}\text { Quality characteristics or } \\
\text { checking parameter }\end{array}$ & Standard & $\begin{array}{l}\text { Inspection } \\
\text { method }\end{array}$ & $\begin{array}{l}\text { Inspection } \\
\text { equipment }\end{array}$ & $\begin{array}{l}\text { Inspection } \\
\text { record }\end{array}$ & \\
\hline \multirow[t]{7}{*}{1} & \multirow[t]{7}{*}{ Selection } & \multirow[t]{7}{*}{ Raw skin } & \multirow[t]{7}{*}{$\begin{array}{l}\text { RHS QC } \\
\text { section }\end{array}$} & \multirow[t]{7}{*}{$\begin{array}{l}\text { Grade of raw } \\
\text { skin }\end{array}$} & $\begin{array}{l}\text { Hole, knife cut, heat, putrefy, } \\
\text { Brand mark, Wound, Shape, } \\
\text { crack }\end{array}$ & \multirow[t]{2}{*}{$\begin{array}{l}\text { RHS } \\
\text { inspection } \\
\text { standard }\end{array}$} & Visual & Manual & \multirow[t]{7}{*}{$\begin{array}{l}\text { RHS } \\
\text { inspection } \\
\text { record chart }\end{array}$} & \\
\hline & & & & & Size & & Measuring & Measuring table & & \\
\hline & & & & & $\begin{array}{l}\text { Pilling standard WS }=0.60 \\
\mathrm{~m} \text { and }\end{array}$ & \multirow[t]{5}{*}{ FIFO } & \multirow[t]{5}{*}{ Measuring } & \multirow[t]{5}{*}{ Tape measure } & & \\
\hline & & & & & Air dry $=1.5 \mathrm{~m}$ & & & & & \\
\hline & & & & & Piling date WS $<2$ weeks and & & & & & \\
\hline & & & & & Air dry $<2$ month & & & & & \\
\hline & & & & & Trimming: neck part half moon & & & & & \\
\hline
\end{tabular}

Table 12: Quality control process chart for RHS.

same sample. But for comparison between the actual situation before and after the implementation I recommend to use same number of pieces (Figure 10).

Discussion on the above figure: The figure shows that the total rejected pieces of leather before implementing the countermeasures like preparing, awareness creation and implementing quality control process chart, quality control check sheet format and standardized operating procedure, were 8164 pcs but after implementing the countermeasures the total rejected pieces of leather becomes 5241 pieces. 2923 pieces of finished skin leather is saved from being rejected. Due to the reduction of excessive trimming from $14,879.92 \mathrm{~kg}$ to 8,524 
Citation: Hailu H, Tabuchi H, Ezawa H, Jilcha K (2017) Reduction of Excessive Trimming and Reject Leather by Integration of 7 QC Tools and QC Story Formula: The Case Report of Sheba Leather PLC. Ind Eng Manage 6: 223. doi:10.4172/2169-0316.1000223

Page 13 of 15

\begin{tabular}{|c|c|c|c|c|c|}
\hline \multirow[t]{2}{*}{ S.No. } & \multirow[t]{2}{*}{ Trimming area } & \multicolumn{2}{|c|}{ Causes for trimming } & \multicolumn{2}{|c|}{ Trimmed Weight in kg } \\
\hline & & & & \multirow{2}{*}{$\begin{array}{c}\text { Before } \\
1,012.26 \mathrm{~kg}\end{array}$} & \multirow{2}{*}{\begin{tabular}{c|} 
After \\
641.26
\end{tabular}} \\
\hline & \multirow[t]{3}{*}{ Dry trimming - skin leather } & Abnormal trim & Trimmer & & \\
\hline & & \multirow[t]{2}{*}{ Mechanical trim } & $\begin{array}{c}\text { Machines (Buffing, Rotary, stacking, Dry } \\
\text { shaving and Setting out) }\end{array}$ & $3,036.8 \mathrm{~kg}$ & $1,873.60$ \\
\hline & & & Total & 4049.06 & $2,514.86$ \\
\hline & \multirow{10}{*}{$\begin{array}{l}\text { Final dry trimming - skin } \\
\text { leather }\end{array}$} & \multirow[t]{8}{*}{ Defect } & Knife cut & $1367.10 \mathrm{~kg}$ & 248.60 \\
\hline & & & Hole & $810.99 \mathrm{~kg}$ & 493.65 \\
\hline & & & Back bone & $509.78 \mathrm{~kg}$ & 310.30 \\
\hline & & & Shape & $451.84 \mathrm{~kg}$ & 275.03 \\
\hline & & & Wound & $115.86 \mathrm{~kg}$ & 70.52 \\
\hline & & & Brand mark & $81.10 \mathrm{~kg}$ & 49.36 \\
\hline & & & Folding & $46.34 \mathrm{~kg}$ & 28.21 \\
\hline & & & Total & $3,383 \mathrm{~kg}$ & 1475.67 \\
\hline & & \multirow[t]{2}{*}{ Mechanical } & Buffing & $534 \mathrm{~kg}$ & 325 \\
\hline & & & Total & $3,917 \mathrm{~kg}$ & $1,800.67$ \\
\hline & \multirow[t]{2}{*}{ Wet trimming Skin leather } & \multirow[t]{2}{*}{ Mechanical } & Wet shaving & $6,913.86 \mathrm{~kg}$ & $4,208.46$ \\
\hline & & & Total & $6,913.86 \mathrm{~kg}$ & $4,208.46$ \\
\hline & & & Grand Total & $14,879.92 \mathrm{~kg}$ & $8,524 \mathrm{~kg}$ \\
\hline
\end{tabular}

Table 13: Trimmed weight in kg. (From 266,387 pieces).

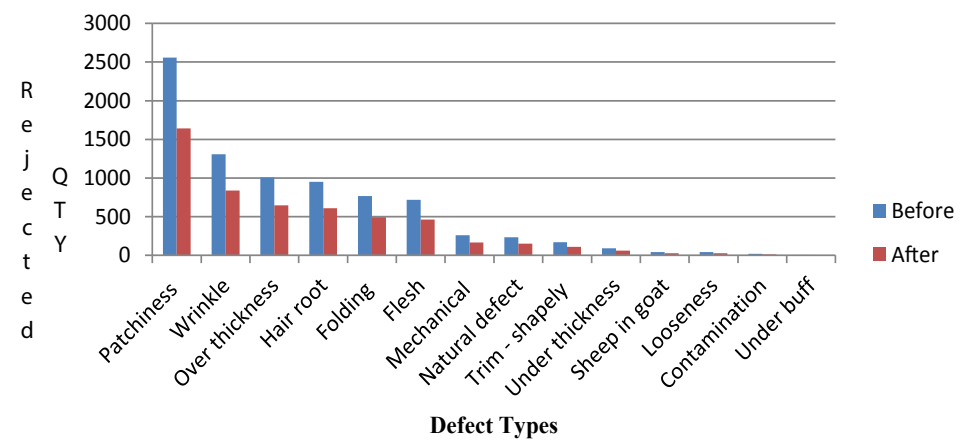

Figure 10: Rejected leather quantity versus defect types (from 158,884 pieces).

\begin{tabular}{|c|c|c|c|c|c|}
\hline Key Performance Indicators & \multicolumn{2}{|c|}{ Before, Target, Improvement (\%) result } & \multicolumn{2}{|c|}{ After, Target, Improvement (\%) result } & \multirow{2}{*}{$\begin{array}{c}\text { Deviation from } \\
\text { target }\end{array}$} \\
\hline \multirow[t]{3}{*}{ KPI 1: Trimming Leather skin } & Before & $14,879.92 \mathrm{~kg}$ & After & 8524 kg & \\
\hline & Target & $7439.96 \mathrm{~kg}$ & Target & $7439.96 \mathrm{~kg}$ & \\
\hline & Improvement (\%) & $50 \%$ & Improvement (\%) & $42.71 \%$ & $-7.29 \%$ \\
\hline \multirow[t]{3}{*}{ KPI 2: Finished Skin Reject } & Before & $5.14 \%$ & Actual & $3.3 \%$ & \\
\hline & Target & $2.57 \%$ & Target & $2.57 \%$ & \\
\hline & Improvement (\%) & $50 \%$ & Improvement (\%) & $35.79 \%$ & $-14.21 \%$ \\
\hline \multirow{3}{*}{$\begin{array}{l}\text { KPI 3: Size Increment From } \\
\text { Input }\end{array}$} & Before & $2.4 \%$ (minus) & Actual & $2.2 \%+\mathrm{Ve}$ & \\
\hline & Target & $1.2 \%$ (positive) & Target & $1.2 \%+V e$ & \\
\hline & Improvement (\%) & $50 \%$ & Improvement (\%) & $191.67 \%$ & $+141.67 \%$ \\
\hline
\end{tabular}

Table 14: Comparison of target (before) and actual result (after).

$\mathrm{kg}$ and reduction of defects on the leather (158,884 pieces) from $5.14 \%$ to $3.3 \%$, the output average area of finished is 3.65 square feet [6]. The previous average area of the skin leather before implementation were 3.57. The improvement is $(3.65-3.57 / 3.65) * 100=2.2 \%$

Confirmation of the trimming leather, finished skin reject and size area increment before, target and improvement\% results were compared with after. Based on this, the three key performance indicators are compared as shown below (Table 14).

Discussion on the table: From the table it is shown that for KPI 1 and KPI 2, the target is not achieved. Because, in the counter measure action plan, it is suggested to provide technical or practical training for production, maintenance and quality control staffs. But, since there is no training center, it was difficult to deliver the training. We simply focus on mobilization and awareness creation to all required listed staffs (Figure 11).

\section{Standardization and training - SOP, photo}

This step is key for an organization. Improvements must be included in the working procedure. In general, by following the Plan - Do - Check - Act cycle, after achieving results, these results sholud be standardized and must be base line for next activity planning (i.e following Standardize Do Check Act). One thing that must not be forget at this stage of problem solving approach is create an awareness 
Citation: Hailu H, Tabuchi H, Ezawa H, Jilcha K (2017) Reduction of Excessive Trimming and Reject Leather by Integration of 7 QC Tools and QC Story Formula: The Case Report of Sheba Leather PLC. Ind Eng Manage 6: 223. doi:10.4172/2169-0316.1000223
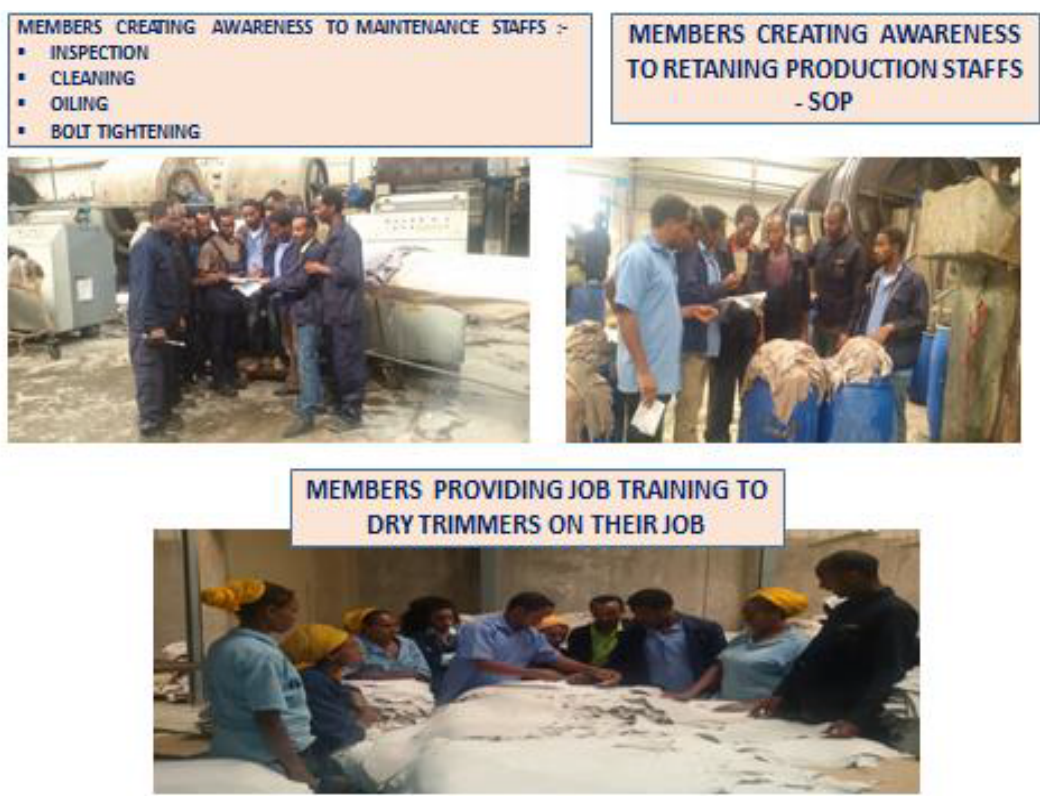

Figure 11: Discussion on the table.

CFT Progress Presentation by Quality Manager - Standardize
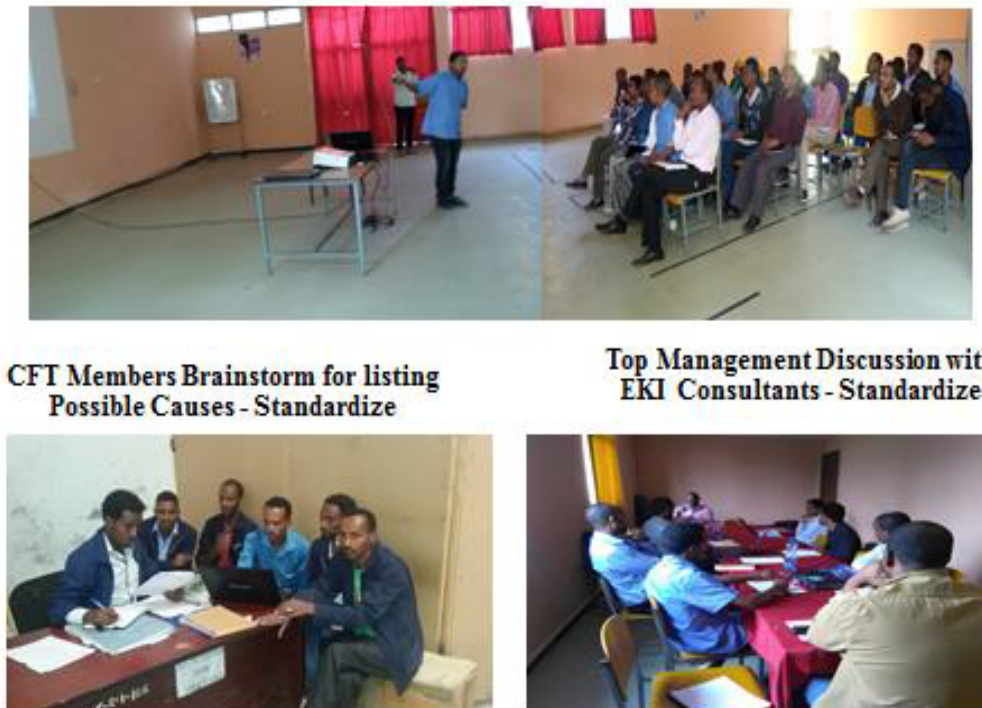

Top Management Discussion with EKI Consultants - Standardize

Figure 12: Improvements must be included in the working procedure.

or conducting training regarding to the results and standards to respected employees is very manadatory. Based on this, the achieved resuilts were presented to company managements by QC Manager. The following table was prepared as a control point for reduction of excessive trimming and rejected leather (Figure 12 and Table 15).

\section{Future plan}

In PDCA Cycle, chronic problems are prioritized as per their volume, size or depth. After confirmation of being solved the first ranked problem, the management or team agreed on to solve the second ranked problem or to implement any left countermeasures that did not implement due to various reasons. So, for successful completion of this improvement activity, a detailed action plan should be prepared. Most of the manufacturing companies did not give attention to this activity. Sheba Leather Industry managements, cross functional team members, EKI staff and JICA expert were discuss each other on left counter measures specifically on conducting technical training. After the agreement, the following future action plan was developed and created an awareness to responsible persons (Table 16).

\section{Summary of Technical Report}

This is technical report focused on minimization of long delivery time of shoe by integration of 7QC tools and Quality control story formula. At the time of the project, there was customer complaint. 
Citation: Hailu H, Tabuchi H, Ezawa H, Jilcha K (2017) Reduction of Excessive Trimming and Reject Leather by Integration of 7 QC Tools and QC Story Formula: The Case Report of Sheba Leather PLC. Ind Eng Manage 6: 223. doi:10.4172/2169-0316.1000223

Page 15 of 15

\begin{tabular}{|c|c|c|c|c|c|c|c|}
\hline What? & When? & Where? & Who? & How? & Why? & \multirow{2}{*}{$\begin{array}{l}\text { Control } \\
\text { Point }\end{array}$} & \multirow[t]{2}{*}{ Monitoring } \\
\hline Action & Duration & Location & Person in charge & Method & Objective & & \\
\hline $\begin{array}{l}\text { Implementing } \\
\text { Skin Leather } \\
\text { Standardized } \\
\text { Operating } \\
\text { Procedure }\end{array}$ & $\begin{array}{l}\text { Always when Skin } \\
\text { Leather Produced }\end{array}$ & $\begin{array}{l}\text { RHS, Beam House, Tanning, } \\
\text { Retanning, Crust Preparation }\end{array}$ & $\begin{array}{l}\text { Skin Tannery } \\
\text { Production Foreman, } \\
\text { Operator }\end{array}$ & $\begin{array}{l}\text { Preparing New SOP } \\
\text { for Every Product }\end{array}$ & $\begin{array}{l}\text { Producing Quality } \\
\text { Skin Leather } \\
\text { Product }\end{array}$ & $\begin{array}{l}\text { Parameters } \\
\text { for skin } \\
\text { leather }\end{array}$ & $\begin{array}{l}\text { Skin Tannery } \\
\text { Production } \\
\text { Head }\end{array}$ \\
\hline $\begin{array}{l}\text { Implementing Four } \\
\text { Basic Autonomous } \\
\text { Maintenance } \\
\text { Activities }\end{array}$ & $\begin{array}{l}\text { Always when Skin } \\
\text { Leather Produced }\end{array}$ & $\begin{array}{l}\text { Beam House, Tanning, } \\
\text { Retanning, Crust Preparation } \\
\text { Machines and drums }\end{array}$ & $\begin{array}{l}\text { Skin Production } \\
\text { Maintenance Staffs - } \\
\text { Mechanics }\end{array}$ & $\begin{array}{l}\text { Using Inspection, } \\
\text { Cleaning, Oiling and } \\
\text { Bolt - Tightening } \\
\text { Standard Format }\end{array}$ & $\begin{array}{l}\text { Improving the } \\
\text { Availability of } \\
\text { Machines on The } \\
\text { Production }\end{array}$ & $\begin{array}{l}\text { Four Basic } \\
\text { AM Activities }\end{array}$ & $\begin{array}{l}\text { Tannery } \\
\text { Maintenance } \\
\text { Manager }\end{array}$ \\
\hline $\begin{array}{l}\text { Implementing } \\
\text { Quality Control } \\
\text { Process Chart }\end{array}$ & $\begin{array}{l}\text { Always when Skin } \\
\text { Leather Produced }\end{array}$ & $\begin{array}{l}\text { RHS, Beam House, Tanning, } \\
\text { Retanning, Crust Preparation }\end{array}$ & $\begin{array}{l}\text { Skin Quality } \\
\text { Inspector }\end{array}$ & $\begin{array}{l}\text { Using Quality } \\
\text { Control Process } \\
\text { Chart }\end{array}$ & $\begin{array}{l}\text { Preventing } \\
\text { Making Reject } \\
\text { Products }\end{array}$ & $\begin{array}{l}\text { Defect types } \\
\text { as per the } \\
\text { section }\end{array}$ & $\begin{array}{l}\text { Quality Control } \\
\text { Manager }\end{array}$ \\
\hline $\begin{array}{l}\text { Consistent Follow } \\
\text { Up }\end{array}$ & Once a Week & Skin Tannery Production & $\begin{array}{l}\text { Production, Quality, } \\
\text { Maintenance } \\
\text { Managers }\end{array}$ & $\begin{array}{l}\text { Establishing } \\
\text { Standardized } \\
\text { Meeting Schedule }\end{array}$ & $\begin{array}{l}\text { Solving Skin } \\
\text { Tannery Problems }\end{array}$ & $\begin{array}{l}\text { Holding } \\
\text { once a week } \\
\text { meeting }\end{array}$ & Operation DGM \\
\hline $\begin{array}{l}100 \% \text { raw skin } \\
\text { inspection }\end{array}$ & Daily & RHS Store & RHS QC Selectors & $\begin{array}{l}\text { Using RHS QC } \\
\text { check sheet format }\end{array}$ & $\begin{array}{l}\text { Not to pass } \\
\text { defected raw skin }\end{array}$ & $\begin{array}{l}\text { RHS defect } \\
\text { types }\end{array}$ & QC Manager \\
\hline
\end{tabular}

Table 15: Standardization of control points.

\begin{tabular}{|c|c|c|c|c|c|c|c|c|c|c|c|}
\hline \multirow{3}{*}{\begin{tabular}{|c|} 
Reasons \\
for trimming \\
and \\
Rejection
\end{tabular}} & \multirow{3}{*}{$\begin{array}{l}\text { WHAT? } \\
\text { Problem }\end{array}$} & \multirow{3}{*}{$\begin{array}{l}\text { WHERE? } \\
\text { Location }\end{array}$} & \multirow{3}{*}{$\begin{array}{c}\text { HOW? } \\
\begin{array}{c}\text { Recommended } \\
\text { action }\end{array}\end{array}$} & \multicolumn{6}{|c|}{ WHEN? } & \multirow{3}{*}{\begin{tabular}{|c|} 
WHO? \\
Person in charge
\end{tabular}} & \multirow{3}{*}{$\begin{array}{c}\text { WHY? } \\
\text { Objective }\end{array}$} \\
\hline & & & & \multicolumn{6}{|c|}{ Duration 20016} & & \\
\hline & & & & Sep. & Oct. & Nov. & Dec. & Jan. & Feb. & & \\
\hline $\begin{array}{c}\text { Wet and } \\
\text { dry trimming } \\
\text { mechanical }\end{array}$ & \begin{tabular}{|c|} 
Not \\
providing \\
adjustment \\
training
\end{tabular} & $\begin{array}{l}\text { Wet shaving } \\
\text { machine }\end{array}$ & $\begin{array}{l}\text { Adjustment } \\
\text { training }\end{array}$ & $\rightarrow$ & & & & & & $\begin{array}{c}\text { Re-tanning } \\
\text { supervisor, CFT }\end{array}$ & $\begin{array}{c}\text { To prevent } \\
\text { mechanical defect }\end{array}$ \\
\hline Knife cut & $\begin{array}{l}\text { Selector } \\
\text { checking } \\
\text { problem }\end{array}$ & Raw skin store & $\begin{array}{l}\text { Training, } 100 \% \\
\text { inspection }\end{array}$ & & $\rightarrow$ & & & & & QC manager, CFT & $\begin{array}{c}\text { To prevent passing } \\
\text { defect }\end{array}$ \\
\hline $\begin{array}{l}\text { Abnormal } \\
\text { trim }\end{array}$ & $\begin{array}{l}\text { Unskilled } \\
\text { trimmer }\end{array}$ & $\begin{array}{l}\text { Wet and dry } \\
\text { trimming }\end{array}$ & $\begin{array}{c}\text { Providing } \\
\text { trimming training }\end{array}$ & & & $\rightarrow$ & & & & $\begin{array}{l}\text { Skin production, } \\
\text { CFT }\end{array}$ & $\begin{array}{c}\text { To increase area of } \\
\text { leather }\end{array}$ \\
\hline $\begin{array}{l}\text { Over } \\
\text { thickness }\end{array}$ & Adjustment & $\begin{array}{l}\text { Buffing, Wet and } \\
\text { Dry shaving }\end{array}$ & Training & & & & $\rightarrow$ & & & $\begin{array}{c}\text { Skin Crust } \\
\text { supervisor, CFT }\end{array}$ & $\begin{array}{l}\text { To fulfill the } \\
\text { customer } \\
\text { requirement }\end{array}$ \\
\hline Folding & $\begin{array}{c}\text { Poor feeding } \\
\text { system }\end{array}$ & $\begin{array}{c}\text { Setting out, Vibratory } \\
\text { stacking }\end{array}$ & Training & & & & & $\rightarrow$ & $\rightarrow$ & Skin production & $\begin{array}{l}\text { To prevent the } \\
\text { leather from } \\
\text { damaged }\end{array}$ \\
\hline
\end{tabular}

Table 16: Future activity plan for solving.

This was originated from not achieving delivery time of Venice model shoe. The management via brainstorming agreed on minimization of long delivery time theme to be tackled by the project. Meanwhile, cross functional team was established from different departments related to theme. The team analyzed original situation of the problem starting from order preparation to final storage time. They confirmed that more than 3 months are taken to produce 240 pairs of shoe. Therefore, the team set a target to reduce by 50 percent. An action plan contained problem solving steps was prepared. Based on studied original situation, cause analysis was done to identify critical root causes. During analysis fish bone diagram, why - why analysis and cause priority number criteria were used. After identifying critical root causes, possible countermeasures were established using criteria's. The possible countermeasures were implemented as per the countermeasure action plan. After the completion of the implementation period, the team evaluated the process and certain achieving tangible result by shortening delivery time to $18,236.55 \mathrm{~min}$. This result is control point of Venice model shoe. The team was trained to standardize, maintain, and improve this control point. At the end, future plan was prepared to implement left best solutions and to solve another new theme.

\section{References}

1. Bekele H (2013) Continuous Improvement in Safety, Quality, and Productivity at Crystal Tannery Share Company.
2. Agency CS (2012) Large and Medium Scale Manufacturing and Electricity Industries Survey, Addis Ababa: The Federal Democratic Republic of Ethiopia.

3. Franco LM, Newman J, Murphy G, Mariani E (1997) Achieving Quality Through Problem Solving and Process Improvement.

4. The Study on Quality and Productivity Improvement in Ethiopia. Ethiopia Kaizen Institute Manual. First Edition March, 2011.

5. Katsuya Hosotani: The Quality Control Problem Solving Approach - Solving Workplace Problems the Japanese Way book.

6. Business Plan 2015 to 2020 E.C. June 2015. Sheba Leather Industry P.L.C. 